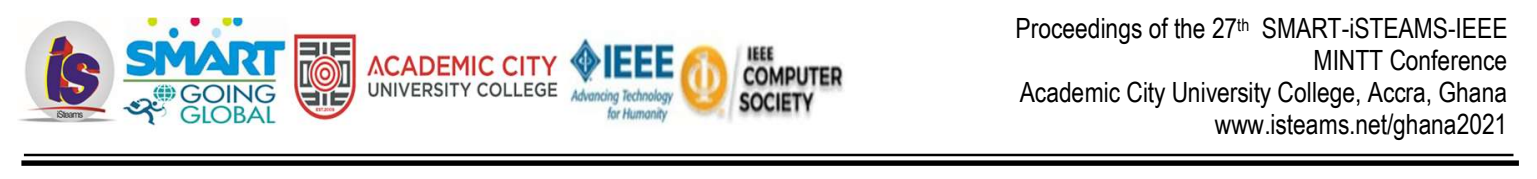

\title{
Office Management in the COVID-19 Era
}

\author{
${ }^{1}$ Adenekan, T.E. (Ph.D.) \& ${ }^{2}$ diake, ${ }^{2}$ C. Omoye \\ 1Department of Information Management, Lead City University, Ibadan, Nigeria \\ 2Office Technology and Management Department, Lagos State Polytechnic, Ikorodu, Lagos, Nigeria \\ E-mails: lizzyadenekan@yahoo.com; christianaomoye@yahoo.com \\ Phones: +2348033562360; +23408023656549
}

\begin{abstract}
By the time the World Health Organization ("WHO") upgraded the status of the novel Coronavirus Disease (officially known as COVID-19) outbreak from an epidemic to a global pandemic on 11th March, 2020, the virus had already travelled beyond Wuhan, China, its point of original outbreak in December 2019 and crossed international borders. Given the rapid rate of infection and increasing number of deaths in the wake of the unprecedented spread of the virus, various emergency measures were urgently deployed by local, state, national and multilateral authorities to contain the outbreak. Besides being a public health crisis, COVID-19 continues to trigger severe social and economic consequences for individuals, corporates and governments across the world. Specifically, offices were closed for several months, during this period, the office management took another dimension whereby offices are operated on-line and virtually. This paper analyses the key socio-economic consequences of COVID-19 on office Management, and measures taken by Office managers for mitigating its effect on the operations of organizations.
\end{abstract}

Keywords: Office Management, COVID-19 era, Organizations.

Proceedings Reference Format

Adenekan, T.E.. \& Idiake, C. Omoye (2021): Office Management in the COVID-19 Era. Proceedings of the 27th iSTEAMS Multidisciplinary Innovations \& Technology Transfer (MINTT) Conference. Academic City University College, Accra, Ghana. June, 2021. Pp 341 www.isteams.net/ghana2021. DOI - https://doi.org/ 10.22624/AIMS/iSTEAMS-2021/N27P28 